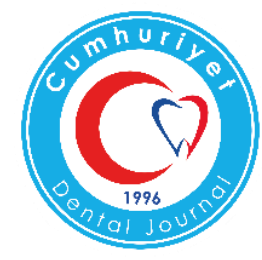

\title{
EFFECT OF CORONAL BARRIER THICKNESS ON FRACTURE STRENGTH OF IMMATURE TEETH
}

\author{
Koronal Bariyer Kalınlığının Gelişimi Tamamlanmamış Dişlerin Kırılma \\ Dayanımına Etkisi
}

Selen KÜÇÜKKAYA EREN, Sevinç ASKERBEYLİ ÖRS, Hacer AKSEL

\begin{abstract}
Makale Kodu/Article Code : :432743
Makale Gönderilme Tarihi $\quad: 11.06 .2018$

Kabul Tarihi

: 16.10 .2018
\end{abstract}

\section{ABSTRACT}

Objectives: Secondary trauma is one of the main causes of root fracture in regenerative endodontic cases. The aim of this study was to compare the influence of Biodentine that placed with different thicknesses as a coronal barrier material on the fracture strength of simulated immature teeth.

Materials and Methods: The root canals of 65 human maxillary central incisors were instrumented using Peeso reamers to simulate immature teeth. Ten teeth with no access cavity preparation were selected to the negative control group. The access cavities of the remaining 55 teeth were prepared. Among them, the root canals of 10 teeth were filled with calcium hydroxide as the positive control group. Forty-five teeth were randomly divided into 3 groups according to the application thicknesses of Biodentine $(\mathrm{n}=15)$; Group 1: 2-3 mm thick coronal plug, Group 2: 5-6 mm thick coronal plug, Group 3: complete canal obturation. After the storage period of 4 weeks, fracture testing was performed using a universal testing machine. One-way analysis of variance and Tukey tests were used to analyze the data.

Results: No significant difference was found among the positive control, group 1 and group $2(p>0.05)$. Although there was no significant difference between the negative control $(p>0.05)$ and group 3, these groups indicated the highest fracture strength values $(p<0.05)$. All fractures occurred through the cervical region of the root as horizontally or obliquely.

Conclusions: No significant reinforcement effect was obtained when Biodentine was used as a coronal plug. The complete root canal obturation of simulated immature teeth using Biodentine provided significantly the best reinforcement effect. The coronal plug thickness had no influence on the fracture strength of immature teeth.

Key Words: calcium silicate cement, endodontics, regeneration, tooth fractures
ÖZ

Amaç: Rejeneratif endodontik tedavi görmüş vakalarda kök kırıklarının en önemli nedenlerinden biri sekonder travmalardır. $\mathrm{Bu}$ çalışmanın amacı, koronal bariyer materyali olarak farklı kalınlıklarda yerleştirilen Biodentine'in gelişimi tamamlanmamış dişlerin kırılma dayanımına etkisini incelemektir.

Gereç ve Yöntem: Gelişimi tamamlanmamış diş simulasyonu için, 65 adet üst santral dişin kök kanalları Peeso reamerlar ile genişletildi. On dişte giriş kavitesi açılmadı ve bunlar negatif kontrol grubu olarak ayrıldı. Giriş kavitesi açılmış 55 dişin, 10 tanesi pozitif kontrol olarak ayrıldı ve bu dişlerin kök kanalına kalsiyum hidroksit yerleştirildi. Kök kanallarına yerleştirilen Biodentine'in kalınlığına göre 45 diş rastgele olacak şekilde 3 gruba ayrıldı $(\mathrm{n}=15)$; Grup 1: 2-3 mm kalınlıkta koronal bariyer, Grup 2: 5-6 mm kalınlıkta koronal bariyer, Grup 3: tüm kanalın dolumu. Dört haftalık bekleme süresi sonrası, kırılma dayanımı analizi universal test cihazı ile gerçekleştirildi. Tek yönlü varyans analizi ve Tukey testleri ile istatistiksel analiz yapıldı.

Bulgular: Pozitif kontrol, Grup 1 ve Grup 2 arasinda anlamlı fark yoktu $(p>0,05)$. Negatif kontrol ve Grup 3 en yüksek kırılma dayanımı değerlerini gösterdi $(p<0,05)$ ve bu iki grup arasında anlamlı fark yoktu $(p>0,05)$. Tüm kırıklar dişlerin servikal kısmında yatay veya oblik olarak meydana geldi.

Sonuçlar: Biodentine koronal bariyer olarak kullanıldığında dişlerin kırılma dayanımı üzerinde anlamlı bir güçlendirici bir etkisi olmadı. Kök kanalı tamamen Biodentine ile doldurulduğunda en iyi güçlendirme etkisi oluştu. Koronal bariyer kalınlığının gelişimi tamamlanmamış dişlerin kırılma dayanımına herhangi bir etkisi olmadı.

Anahtar Kelimeler: diş kırıkları, endodonti, kalsiyum silikat siman, rejenerasyon

Department of Endodontics, Faculty of Dentistry, Hacettepe University, Ankara, Turkey. 


\section{INTRODUCTION}

Traumatic dental injuries frequently affect the maxillary anterior teeth of young patients and often result in arrested root development due to pulpal necrosis. ${ }^{1}$ The root canal treatment of these teeth is challenging because of wide open apices and thin dentinal walls. ${ }^{2}$

Historically, calcium hydroxide $\left(\mathrm{Ca}(\mathrm{OH})_{2}\right)$ was used for apexification of infected immature teeth. ${ }^{2}$ However, this treatment approach requires multiple visits and patient compliance. Besides, there is a risk of increased susceptibility to fracture because of long-term $\mathrm{Ca}(\mathrm{OH})_{2}$ treatment. ${ }^{2}$ To overcome these concerns, one-step apexification using mineral trioxide aggregate (MTA), a calcium silicate-based cement, was proposed. ${ }^{3}$ Despite the several desirable properties of this material including good sealing ability, biocompatibility and bioactivity ${ }^{3}$, no increase in the root length and thickness of dentinal walls can be obtained with this treatment. ${ }^{4}$ According to recent studies, fracture was the primary cause of failure in immature teeth treated with one-step apexification using a calcium silicate-based cement.,

Currently, regenerative endodontic treatment is an alternative approach to provide root development in immature teeth. ${ }^{6}$ The treatment procedure involves the disinfection of the root canal system, the formation of a blood clot by inducing bleeding inside the root canal and the placement of a biocompatible coronal barrier to create a hermetic seal. ${ }^{7}$ In recent years, several case studies have reported successful outcomes in the treatment of infected immature teeth using regenerative endodontic procedures. ${ }^{7-13}$ In the majority of these cases, calcium silicate-based cements including MTA and Biodentine were used as coronal barrier materials., ${ }^{70-13}$ Despite its favorable biologic properties, MTA has some drawbacks such as poor handling characteristics, low wash-out resistance and long setting time. ${ }^{14}$ Biodentine was introduced as a dentin substitute under resin composite restorations and reported to exhibit short setting time and high mechanical properties. ${ }^{15}$

It was reported that secondary trauma was the cause of root fracture in $85 \%$ of cases. ${ }^{16}$ Although there is no definite protocol to provide the best outcome in the treatment of necrotic immature teeth, a coronal plug of approximately $3 \mathrm{~mm}$ thickness has been suggested to be sufficient for regenerative endodontic procedures. ${ }^{17}$ However, the optimal thickness of a coronal barrier is not clear. Positive outcomes have been reported after regenerative endodontic treatment in previous case reports in which barrier materials at different thicknesses were applied..$^{9-11,13}$ The thickness of coronal plug may affect the fracture strength of immature teeth treated with regenerative endodontic procedures. Therefore, the aim of this study was to compare the influence of placing Biodentine as a barrier material at different thicknesses on the fracture strength of simulated immature teeth.

\section{MATERIALS AND METHODS}

\section{Specimen Selection}

After approval by the ethics committee (Ethics Board No: 18/233), 65 freshly extracted human maxillary central incisors were selected and inspected under magnification to confirm the absence of caries, cracks, abrasions, resorptions or fractures. The buccolingual and mesiodistal dimensions of each tooth were measured using a digital caliper (Mitutoyo, Hampshire, UK). For standardization purposes, teeth with similar dimensions and a length of $20 \pm 0.5 \mathrm{~mm}$ were used.

\section{Treatment Procedures}

The apical $3 \mathrm{~mm}$ of each root-end was removed to simulate immature root apices. Randomly selected 10 teeth were assigned to the negative control group with no access cavity preparation. Their root canals were instrumented from apical to coronal direction using Peeso reamers (Dentsply Maillefer, 
Ballaigues, Switzerland) up to size 5 to simulate immature teeth. ${ }^{18}$ Irrigation was performed only with distilled water in this group.

Endodontic access cavities were prepared in the remaining 55 teeth using a diamond round bur attached to a high-speed handpiece. To simulate immature root apices, the root canals were prepared with Peeso reamers (Dentsply Maillefer) between \#1 and \#5 at 1 $\mathrm{mm}$ beyond the apex. The root canals were irrigated with $1 \mathrm{ml}$ of $2.5 \%$ sodium hypochlorite $(\mathrm{NaOCl})$ between the instruments. The final irrigation was performed with the sequential use of $5 \mathrm{ml}$ of $2.5 \% \mathrm{NaOCl}, 5 \mathrm{ml}$ of $17 \%$ ethylenediaminetetraacetic acid (EDTA) and 5 $\mathrm{ml}$ of distilled water. Finally, the root canals were dried using paper points. $\mathrm{Ca}(\mathrm{OH})_{2}$ was placed in the root canals of 10 teeth with a lentulo spiral (Dentsply Maillefer) and these teeth served as the positive control.

Forty-five teeth were randomly distributed into 3 groups $(n=15)$ according to the thickness of barrier material (Fig. 1A-C).
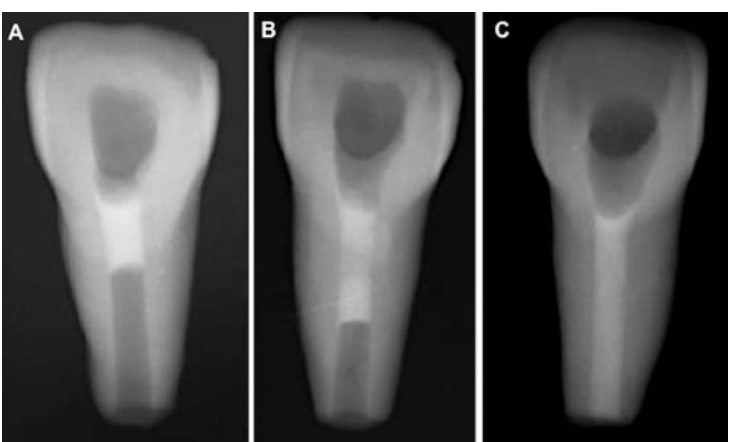

Figure 1. Representative images of groups obturated with Biodentine. (A) 2-3-mm coronal plug, (B) 5-6-mm coronal plug and $(\mathrm{C})$ complete obturation.

In these groups, Biodentine (Septodont, Saint Maur des Fosses, France) was mixed according to the manufacturer's instructions and delivered to the root canals from the coronal access with a carrier (MTA Endo gun, Dentsply Maillefer). In group 1, Biodentine was condensed with a hand plugger (Buchanan Hand Plugger, SybronEndo, Orange, USA) to obtain a 2-3 mm thick coronal plug (Fig. 1A). In group 2, Biodentine was condensed with the hand plugger to obtain a 5-6 mm thick coronal plug (Fig. 1B). In group 3, the root canals were completely obturated with Biodentine using the hand plugger (Fig. 1C). In groups 1 and 2, the thickness of barrier material was arranged using customized gutta-percha points. A guttapercha point that fits tightly in the root canal was shortened to the appropriate length for each specimen and temporarily inserted into the root canal from apical to coronal direction. ${ }^{19}$ The depth of space left for the barrier material was confirmed with a periodontal probe. The gutta-percha placement facilitated the material condensation, prevented apical movement of the material and allowed standardization of coronal barrier thickness. Each gutta percha point was removed after the material setting completed. The thickness of barrier material and uniform obturation were confirmed with periapical radiographs. Each access cavity was restored with composite resin (Ice, SDI, Bayswater, Victoria, Australia). All specimens were stored at $37^{\circ} \mathrm{C}$ and $100 \%$ humidity for 4 weeks.

In this study, a single operator performed the preparation of access cavities and root canals; a second operator performed the obturation procedures.

\section{Fracture test}

The external root surfaces were covered with an impression material (Variotime, Heraeus Kulze, Hanau, Germany) to simulate a periodontal ligament as described in a previous study. ${ }^{20}$ The teeth were vertically embedded in self-curing acrylic resin (Meliodent, Heraeus Kulzer) poured in cylindrical molds, leaving a $2 \mathrm{~mm}$ gap between the top of the resin and the cementoenamel junction. The fracture test was performed using a universal testing machine (Lloyd LR 30K, Fareham, UK). The load was applied on the facial surface at $135^{\circ}$ to the specimen's long axis at a point $3 \mathrm{~mm}$ above the cementoenamel junction. The specimens were loaded at a cross-head speed of 1 $\mathrm{mm} / \mathrm{min}$. The maximum load that fracture occurred was recorded in Newtons (N). 


\section{Statistical Analysis}

Data were evaluated for normal distribution using the Kolmogorov-Smirnov test. Due to the normal distribution of data, the groups were compared using one-way analysis of variance and Tukey tests. The significance level was set at $p=0.05$.

\section{RESULTS}

The fracture strength values of the groups are presented in Table 1.

Table 1. The Mean Peak Load (N) and Standard Deviation (SD) of the Groups

\begin{tabular}{|l|c|c|c|c|}
\hline Groups & $\mathbf{n}$ & Mean \pm SD (N) & Minimum & Maximum \\
\hline Negative control & 10 & $992.47 \pm 70.41^{\mathrm{a}}$ & 863.09 & 1100.01 \\
\hline Positive control & 10 & $688.50 \pm 91.30^{\mathrm{b}}$ & 518.28 & 813.84 \\
\hline Group 1 (2-3 mm coronal plug) & 15 & $696.48 \pm 127.13^{\mathrm{b}}$ & 493.85 & 911.81 \\
\hline Group 2 (5-6 mm coronal plug) & 15 & $797.36 \pm 188.49^{\mathrm{b}}$ & 488.58 & 1088.26 \\
\hline Group 3 (completely obturated) & 15 & $978.13 \pm 134.35^{\mathrm{a}}$ & 682.84 & 1129.56 \\
\hline
\end{tabular}

Different superscript letters indicate significant differences between the groups $(p<0.05)$.

No significant difference was found among the positive control, group 1 and group 2 ( $p>$ 0.05). Although there was no significant difference between the negative control and group $3(\mathrm{p}>0.05)$, these groups indicated the highest fracture strength values $(p<0.05)$. All fractures occurred through the cervical region of the root horizontally or obliquely.

\section{DISCUSSION}

The major purpose of regenerative endodontic treatment is to eliminate infection from the root canal system and to obtain complete root formation. ${ }^{12}$ In this way, long-term complications such as fracture that occurred due to incomplete root development and thin dentinal walls can be prevented..$^{21}$ However, in several studies, the outcome of regenerative endodontic treatment was lower than ideal, because of incomplete formation of root apex, no increase in root length or thickness. ${ }^{11,22,23}$ Although the first indication of root development was usually detected after 6month follow-up ${ }^{9,12,13}$, in a recent study failure was detected after 4-year follow-up indicating the need for long-term follow-up of regenerative endodontic cases. ${ }^{24}$ As the desired outcomes are often obtained after a long period, these teeth are usually prone to fracture for a considerable time after regenerative endodontic treatment. The treatment protocol applied during regenerative endodontic procedures may affect the fracture strength of immature teeth. Therefore, the effect of barrier material thickness on the fracture strength of immature teeth was evaluated in the current study.

Recently, the use of Biodentine during regenerative endodontic treatment has been recommended to prevent teeth discoloration ${ }^{6}$ and to complete the final restoration in the same appointment owing to its short setting time. ${ }^{13,25}$ Moreover, a desirable tissue response is expected with the use of Biodentine due to its biocompatibility and osteogenic potential. ${ }^{26}$ Based on these, Biodentine was used as a barrier material in the present study. The current study model included mature teeth prepared to simulate immature roots. To accomplish this, the root canals were prepared with Peeso reamers beyond the apex after rootend resection similar to previous studies..$^{27,28}$ The load was applied at an angle of $135^{\circ}$ during fracture to simulate a traumatic impact on the facial surface of the crowns. ${ }^{18}$ In the present study, all specimens fractured through the cervical area of the roots indicating that the experimental set-up provided a repeatable system for each trial. ${ }^{29}$

Based on the present findings, the intact immature tooth group presented significantly higher fracture resistance than the coronal plug groups and $\mathrm{Ca}(\mathrm{OH})_{2}$ treatment group. This finding could be related to the adverse effects of access cavity preparation on the fracture strength of teeth. ${ }^{18,19}$ In the current study, each access cavity was restored with composite resin and this probably did not provide adequate strengthening to the cervical root region. It has been suggested that root canal irrigants may negatively alter several properties of dentin such as microhardness, 
elasticity, and flexural strength. ${ }^{30,31}$ Therefore, another explanation for the higher fracture resistance results of the intact group can be the irrigation protocol, which was performed only with distilled water.

According to several studies, the use of $\mathrm{Ca}(\mathrm{OH})_{2}$ as a medicament increases the risk of root fracture. ${ }^{2,32}$ This effect has been associated with the denaturation and hydrolysis process in the organic part of dentin due to the high $\mathrm{pH}$ of $\mathrm{Ca}(\mathrm{OH})_{2}{ }^{32}$ However, in the present study, no significant difference was found between the $\mathrm{Ca}(\mathrm{OH})_{2}$ treatment group and the coronal plug groups. This result may be related to the duration of $\mathrm{Ca}(\mathrm{OH})_{2}$ in the root canal. The duration of $\mathrm{Ca}(\mathrm{OH})_{2}$ medication was 4 weeks in this study. Previously, a significant decrease in fracture strength was reported after 3 months of $\mathrm{Ca}(\mathrm{OH})_{2}$ application, while 1-month medication did not negatively affect the fracture strength of roots. ${ }^{33}$

In the current study, the immature teeth that completely obturated with Biodentine exhibited high fracture resistance similar to the intact immature tooth group. The current findings were in line with several studies that found obturating the root canal completely with a calcium silicate-based cement can enhance the fracture strength of immature teeth. $^{34,35}$ The relatively high elastic modulus of Biodentine may have contributed to this result by providing reinforcement effect. ${ }^{36}$ Also, an apatite-like layer formation between the material and dentin owing to the bioactivity of Biodentine could enhance the fracture resistance of simulated immature teeth. ${ }^{37}$ Interestingly, no significant reinforcement effect was obtained when Biodentine was used as a coronal plug. The complete canal obturation with Biodentine may have created more mechanically homogenous units with dentin compared to partial obturation, thus contributing to the fracture strength of teeth.

In conclusion, the complete root canal obturation of simulated immature teeth using
Biodentine provided the best reinforcement effect. However, unlike regenerative endodontic treatment, no development in root length and thickness is expected with this treatment clinically. ${ }^{4}$ Therefore, when interpreting the present results, the possibility of root development with regenerative endodontic procedures should be taken into account. Although positive outcomes have been reported in various clinical reports that performed regenerative endodontic treatment using different thicknesses of coronal plugs ${ }^{9-}$ ${ }^{11,13}$, development of new tissue is not likely to occur in the area where a biomaterial is placed. ${ }^{17}$ As the thicker coronal plug did not provide an additional contribution to the fracture strength in the current study, a 2-3 mm thick coronal plug application can be recommended for regenerative endodontic procedures, both biologically and mechanically.

\section{Conflicts of interest}

The authors declare no potential conflicts of interest with respect to the authorship and/or publication of this article.

\section{REFERENCES}

1. Hargreaves KM, Diogenes A, Teixeira FB. Treatment options: biological basis of regenerative endodontic procedures. J Endod 2013;39:30-43.

2. Andreasen JO, Farik B, Munksgaard EC. Long-term calcium hydroxide as a root canal dressing may increase risk of root fracture. Dent Traumatol 2002;18:134-137.

3. Torabinejad M, Chivian N. Clinical applications of mineral trioxide aggregate. $\mathrm{J}$ Endod 1999;25:197-205.

4. Jeeruphan $\mathrm{T}$, Jantarat $\mathrm{J}$, Yanpiset $\mathrm{K}$, Suwannapan L, Khewsawai P, Hargreaves KM. Mahidol study 1: comparison of radiographic and survival outcomes of immature teeth treated with either regenerative endodontic or apexification 
methods: a retrospective study. J Endod 2012;38:1330-1336.

5. Silujjai J, Linsuwanont P. Treatment outcomes of apexification or revascularization in nonvital immature permanent teeth: a retrospective study. J Endod 2017;43:238-245.

6. Lin J, Zeng Q, Wei X, Zhao W, Cui M, Gu $\mathrm{J}$, Lu J, Yang M, Ling J. Regenerative endodontics versus apexification in immature permanent teeth with apical periodontitis: a prospective randomized controlled study. J Endod 2017;43:1821-1827.

7. Banchs F, Trope M. Revascularization of immature permanent teeth with apical periodontitis: new treatment protocol? J Endod 2004;30:196-200.

8. Iwaya SI, Ikawa M, Kubota M. Revascularization of an immature permanent tooth with apical periodontitis and sinus tract. Dent Traumatol 2001;17:185-187.

9. Chueh LH, Huang GT. Immature teeth with periradicular periodontitis or abscess undergoing apexogenesis: a paradigm shift. J Endod 2006;32:1205-1213.

10.Jung IY, Lee SJ, Hargreaves KM. Biologically based treatment of immature permanent teeth with pulpal necrosis: a case series. J Endod 2008;34:876-887.

11.Petrino JA, Boda KK, Shambarger S, Bowles WR, McClanahan SB. Challenges in regenerative endodontics: a case series. J Endod 2010;36:536-541.

12.Bukhari S, Kohli MR, Setzer F, Karabucak B. Outcome of revascularization procedure: a retrospective case series. J Endod 2016;42:1752-1759.

13.Bakhtiar H, Esmaeili S, Fakhr Tabatabayi S, Ellini MR, Nekoofar MH, Dummer PM. Second-generation platelet concentrate (platelet-rich fibrin) as a scaffold in regenerative endodontics: a case series. J Endod 2017;43:401-408.
14. Kogan P, He J, Glickman GN, Watanabe I. The effects of various additives on setting properties of MTA. J Endod 2006;32:569-572.

15. Grech L, Mallia B, Camilleri J. Investigation of the physical properties of tricalcium silicate cement-based root-end filling materials. Dent Mater 2013;29:e20-28.

16.Al-Jundi SH. Type of treatment, prognosis, and estimation of time spent to manage dental trauma in late presentation cases at a dental teaching hospital: a longitudinal and retrospective study. Dent Traumatol 2004;20:1-5.

17.Wigler R, Kaufman AY, Lin S, Steinbock $\mathrm{N}$, Hazan-Molina H, Torneck CD. Revascularization: a treatment for permanent teeth with necrotic pulp and incomplete root development. J Endod 2013;39:319-326.

18.Cicek E, Yilmaz N, Kocak MM, Saglam BC, Kocak S, Bilgin B. Effect of mineral trioxide aggregate apical plug thickness on fracture resistance of immature teeth. J Endod 2017;43:1697-1700.

19.Uzunoglu E, Eymirli A, Uyanik MO, Nagas E, Cehreli ZC. Fracture resistance of simulated immature teeth after internal bleaching procedures. Aust Endod J 2017.

20.Chan T, Kucukkaya Eren S, Wong R, Parashos $P$. In vitro fracture strength and patterns in root-filled teeth restored with different base materials. Aust Dent J 2018;63:99-108.

21.Galler KM. Clinical procedures for revitalization: current knowledge and considerations. Int Endod J 2016;49:926-936.

22.Nosrat A, Seifi A, Asgary S. Regenerative endodontic treatment (revascularization) for necrotic immature permanent molars: a review and report of two cases with a new biomaterial. J Endod 2011;37:562-567.

23. Chen MY, Chen KL, Chen CA, Tayebaty F, Rosenberg PA, Lin LM. Responses of immature permanent teeth with infected 
necrotic pulp tissue and apical periodontitis/abscess to revascularization procedures. Int Endod J 2012;45:294-305.

24. Chaniotis A. Treatment options for failing regenerative endodontic procedures: report of 3 cases. J Endod 2017;43:1472-1478.

25. Topcuoglu G, Topcuoglu HS. Regenerative endodontic therapy in a single visit using platelet-rich plasma and Biodentine in necrotic and asymptomatic immature molar teeth: a report of 3 cases. J Endod 2016;42:1344-1346.

26. Bortoluzzi EA, Niu LN, Palani CD, ElAwady AR, Hammond BD, Pei DD, Tian FC, Cutler CW, Pashley DH, Tay FR. Cytotoxicity and osteogenic potential of silicate calcium cements as potential protective materials for pulpal revascularization. Dent Mater 2015;31:1510-1522.

27.Ulusoy OI, Nayir Y, Darendeliler-Yaman S. Effect of different root canal sealers on fracture strength of simulated immature roots. Oral Surg Oral Med Oral Pathol Oral Radiol Endod 2011;112:544-547.

28.Tanalp J, Dikbas I, Malkondu O, Ersev H, Gungor T, Bayirli G. Comparison of the fracture resistance of simulated immature permanent teeth using various canal filling materials and fiber posts. Dent Traumatol 2012;28:457-464.

29. Hemalatha H, Sandeep M, Kulkarni S, Yakub SS. Evaluation of fracture resistance in simulated immature teeth using Resilon and Ribbond as root reinforcements--an in vitro study. Dent Traumatol 2009;25:433-438.

30. Ari H, Erdemir A, Belli S. Evaluation of the effect of endodontic irrigation solutions on the microhardness and the roughness of root canal dentin. J Endod 2004;30:792-795.

31.Zhang K, Kim YK, Cadenaro M, Bryan TE, Sidow SJ, Loushine RJ, Ling JQ, Pashley DH, Tay FR. Effects of different exposure times and concentrations of sodium hypochlorite/ethylenediaminetetraacetic acid on the structural integrity of mineralized dentin. J Endod 2010;36:105-109.

32. White JD, Lacefield WR, Chavers LS, Eleazer PD. The effect of three commonly used endodontic materials on the strength and hardness of root dentin. J Endod 2002;28:828830.

33. Andreasen JO, Munksgaard EC, Bakland LK. Comparison of fracture resistance in root canals of immature sheep teeth after filling with calcium hydroxide or MTA. Dent Traumatol 2006;22:154-156.

34.Karapinar-Kazandag M, Basrani B, TomKun Yamagishi V, Azarpazhooh A, Friedman $\mathrm{S}$. Fracture resistance of simulated immature tooth roots reinforced with MTA or restorative materials. Dent Traumatol 2016;32:146-152.

35.Linsuwanont $\mathrm{P}$, Kulvitit S, Santiwong B. Reinforcement of simulated immature permanent teeth after mineral trioxide aggregate apexification. J Endod 2018;44:163-167.

36. Natale LC, Rodrigues MC, Xavier TA, Simoes A, de Souza DN, Braga RR. Ion release and mechanical properties of calcium silicate and calcium hydroxide materials used for pulp capping. Int Endod J 2015;48:89-94.

37.Elnaghy AM, Elsaka SE. Fracture resistance of simulated immature teeth filled with Biodentine and white mineral trioxide aggregate - an in vitro study. Dent Traumatol 2016;32:116-120.

\section{Corresponding Author}

Selen KÜÇÜKKAYA EREN, DDS, PhD

Department of Endodontics

Faculty of Dentistry,

Hacettepe University

Sihhiye, Ankara/Turkey, 06100

Tel : +903123052260

Fax : +903123104440

E-mail : selenkkkaya@yahoo.com 